\title{
KÖNYVJELZÖ
}

\section{Osztály és tér. A városi társadalom formálódása}

\section{Nigel Thrift-Peter Williams (szerk.): Class and Space. The making of urban society, London: Routledge and Kegan Paul, 1989, 292 p.}

A kötet a városi társadalmi osztályok és rétegek formálódásának térbeli aspektusait vizsgálja az elmúlt 200 évben. A téma jellegébốl adódóan a szerzôk között a humán geográfusok mellett társadalomtörténészek és szociológusok is szerepelnek.

A társadalmi struktúra vizsgálatában a szerzôk többsége John Urry koncepcióját fogadja el: három szférát különít el, a termelési viszonyokat, az állam és a civil társadalom viszonyait. A geográfus Nigel Thrift - bevezetố tanulmányában - a 19. századi angol városi társadalmat elemzi Sheffield és Leeds példáján keresztül. A foglalkozási szerkezet vizsgálata alapján kimutatja, hogy míg Sheffieldben erốs kisburzsoázia volt, addig Leedsben állandóan nôtt azoknak a szakmunkásoknak az aránya, akik középosztályi aspirációkat tápláltak magukban. Így, jónéhány más angol városhoz hasonlóan, Leedsben csak az 1880-as évekre formálódott ki a munkásság politikai identitása, ekkorra viszont Sheffieldben a kisburzsoázia elveszítette politikai integritását.

E két város az osztályképzôdés folyamatának két szélsố pólusát képviseli, a többi angol városban lezajló folyamatok e két modell különbözõ kombinációit jelentették, kisebbnagyobb idốbeli eltéréssel. A szintén geográfus Richard Dennis esettanulmánya kéziratos népszámlálási iratok és levéltári források alapján az ún. alsó-kỏzéposztályt elemzi
Huddersfieldben. A sokrétũ forrás felhasználása teszi lehetơvé Dennis számára, hogy a társadalmi rétegzốdést és a lakóhelyi szegregáció összefüggéseit a korábbiaknál pontosabban feltárja. A szerzố a kisiparosok, kiskereskedốk és a munkásarisztokrácia mikroszintũ vizsgálata alapján szemléletesen illusztrálja a 19. sźázadi angol társadalom alapvetổ jellemzôjét, a két alapvetố osztály közötti , ,köztes" rétegek meghatározó szerepét.

Damaris Rose a West Cornwall-i bányászkörzet átmeneti társadalmi csoportját, a bányász-farmereket vizsgálva, szintén a 19. század második felére koncentrál. A kettôs foglalkozási státusz hagyománya egyes francia és belga bányavidékeken is jellemzó volt. A bányászok földbirtoklási vágya nem csupán a farmermúlthoz való ragaszkodásban rejlett, hanem azzal is magyarázható, hogy a föld múvelése a családtagok számára pótlólagos jövedelemforrást, illetve a családfổnek munkanélküliség esetén végsô menedéket nyújtott.

Peter Williams a lakásviszonyok társadalomtörténetéról ad átfogó képet 1700 és 1901 között. A térbeli szemlélet elsősorban abban jelentkezik, hogy a szerzô a városhálózat átalakulásához kapcsolódva elemzi a lakások társadalmi funkcióinak átalakulását. A 18. században a felsố osztályok által elindított „,fogyasztási forradalom" átformálta a lakások méretét és használatát. Az 1770-es évektôl 
az ipari forradalomhoz kapcsolódva felgyorsult az urbanizáció. A fokozatosan megerôsödô burzsoázia, , ,ez az új osztály az angol történelem ... leginkább család- és otthoncentrikus generációja volt"' (196. o.). Az alsó-középosztály és a munkásság lakásviszonyaiban a viktoriánus korszak hozott döntố változást. A középosztály alsó csoportjai gondosan ügyeltek arra, hogy lakásaik külsóleg is megkülönböztethetôk legyenek a munkásságétól. „,A kiugró ablakfülke azért volt fontos, hogy a házat megkülönböztesse a sima homlokzatú munkáslakásoktól" (196. o.). A munkásarisztokrácia pedig a lakás belsố berendezésében hangsúlyozta a munkásságtól való különállását. Ilyen megkülönböztetố szimbólum volt a mahagóni asztalka és az ugyancsak mahagóni borítású falióra.

A kötet második részéhez szintén Nigel Thrift írta a bevezetô tanulmányt. Thrift a 20 . századi Anglia társadalmának új jelenségeit vizsgálja. Az alapvetố fordulatot a szerzố abban látja, hogy az ,osztályküzdelem heroikus korszakát az osztályok lebomlásának kevésbé látványos korszaka váltotta fel" (288. o.). Ugyanakkor a 80-as évekre a ,,service class" - a második világháború után számbelileg egyre gyarapodó szolgáltatási szférában dolgozók - szinte az új osztállyá szervezôdés jeleit mutatják. A tanulmány elismeri, hogy igen nehéz megvonni a határt a , ,szolgáltató osztály" és a fehérgalléros irodai dolgozók között. Az új társadalmi csoport formálódásának kétségtelen jele, hogy 1971-1981 között a feldolgozó iparban dolgozók aránya 35\%-ról $27 \%$-ra csökkent, ezzel szemben a szolgáltató szféra $45 \%$-ról $53 \%$-ra növelte arányát.

A szolgáltató osztály életmódja a ,,kulturális nemesség" jellegét tükrözi. Gyermekeik háromnegyede továbbtanul az iskolaköteles kor betöltése után, míg a munkások gyermekeinek csak egynegyede. Alapvetố értéknek tekintik a kötelességtudatot, a kemény munkát és az önerốre támaszkodást. Ez a társadalm réteg politikailag szorosan kötốdik a konzer. vatív párthoz. Thrift a 80 -as évek választás geográfiáját elemezve leszögezi, hogy a kon. zervatív párt a legnagyobb sikereit ott érte ahol ez az , ,új középosztály" a domináns tár. sadalmi csoport.

John Urry az irányítás, a management szer. vezeti struktúrájának átalakulását, s ennek szervezeti következményeit az USA példájár elemzi. A teoretikus megfontolások mellett : szerzố részletes empirikus elemzést ad arról. hogy pl. a mérnöki szakma milyen példá nyújtott arra, hogy a tudást a termelésse összekötve a munkaerópiaci pozíciókat erôsí. teni lehet. Ezt a ,,modellt" követte a többi, \& termelést és tudományt összekapcsoló szakmí is.

Philip Cooke a kapitalizmus új jelenségei. nek térbeli következményeirôl ad tömör és precízen fogalmazott áttekintést. A kötetbó. ez a tanulmány felel meg leginkább a címber is sugallmazott szándéknak, valóban a társa. dalom térbeli dimenzióira koncentrál. Az 1960-as évektől kibontakozó gazdasági. társadalmi átalakulás fokozatosan felszámoltc a régiók viszonylagos önállóságát. A városhi erarchia felsố szintje - mint a szolgáltatás szféra látványos bốvülésének fố színtere - elszakadt a korábbi nemzeti-regionális bázisá. tól. A nemzetközi munkamegosztás új rendjé. ben a ,szupranacionális" városokban, pl. New York és London, á specializált szolgálta. tó szféra a világgazdaság egészét szolgálta $\mathbf{k}$ és irányítja. Lefelé haladva a városhierarchiá. ban, térbelileg és tartalmilag is egyre inkábt egy-egy térség, országrész városi alapfunk. cióihoz kapcsolható a szolgáltató szféra.

Ray Forrest és Alan Murie - az új közép. osztályt mint jómódú lakástulajdonost vizs. gálja, hiszen a fogyasztás szférájában a lakás. tulajdon a legfontosabb, identitást meghatá. rozó tényezó. Az 1981. évi brit népszámlálás 
adatai szerint az összes háztartás $57 \%$-ában három vagy annál kevesebb személy él, mégis a lakások $86 \%$-a 7 szobás vagy annál nagyobb. A fiatal menedzser réteg lakásvételi és eladási stratégiáját interjúk alapján mutatják be a szerzôk. A lakásválasztásban a szuburbanizációs folyamat tókésítése mellett gyermekeik taníttatási lehetôsége a meghatározó tényezố. A kötet érdekes tanulmányait elolvasva némi hiányérzet mégis marad az olvasóban. A városi társadalom 19-20. századi átalakulásának fổbb aspektusát tárgyalják a szerzổ , de a tanulmányok egymáshoz kapcsolását nem mindig sikerült megoldani a szerkesztőknek. Természetesen a kutatások jelenlegi szintjén nemigen képzelhetổ el a téma átfogó elméleti bázisra épüló kutatása.

A recenzió írójában a kötet tanulmányai egy sor kérdést vetettek fel, melyekre részben válaszoltak a szerzốk, részben további kutatásokat igényelnek. Úgy véljük, hogy a városi társadalom 19-20. századi átalakulásának térbeli aspektusait vizsgálva a következổ kérdések igényelnek további országonkénti kutatást:

1. Hogyan változott a városhálózat különbözố szintjein a gazdasági tốke funkcionális alakjaihoz kapcsolódó rétegek belsổ szerkezete, illetve az általuk mũködtetett tôke térbeli kerete (helyi piac, nemzeti vagy nemzetközi)? A gazdasági monopolszervezetek a városhierarchia mely szintjeit választják központjukként?

2. A kulturális tổke újratermelését biztosító réteg mennyiben kapcsolódik be a termelés szervezetébe, illetve hogyan tagozódik be a társadalom osztályszerkezetébe? E társadalmi réteg a munkamegosztási viszonyok mellett milyen más dimenziók mentén tagolódik. Milyen mértékû́ a belsố tagoltság, és vannak-e település-specifikus vonásai ennek a tagoltságnak? A termelés szervezetébe való bekapcsolódás jellege és mértéke, illetve tevékeny- ségük jellege alapján a következő csoportok elkülönítését tartjuk szükségesnek a városhierarchia egyes szintjein:

a) A termelés technikai eszközeinek átalakítását és fejlesztését végzõ csoport;

b) A munkafolyamatok felügyeletét és szervezését ellátó csoport;

c) Az információ, az innováció és tudomány termelését és közvetítését végzôk csoportja. Lényeges kérdés, hogy az információáramlás és az innovációterjedés belső rendszerét mennyiben határozzák meg a gazdasági tốke, az állam vagy a helyi közösségek igényei;

d) A társadalmi viszonyok újratermeléséhez, és ezen belül az államhoz kapcsolódó csoportok;

e) A hagyományos értelmiség - a tudás közvetítôi és átadói. Az oktatási rendszer alsó- és középsổ szintjén tevékenykedốk csoportja.

Az új középosztály ezen csoportjai között nem húzható merev határvonal, csak hozzávetôleges statisztikai elkülönítés lehetséges. Ettôl függetlenül e csoportok a kulturális tôke újratermelésében funkcionálisan olyan eltérô szerepet játszanak, amely indokolttá teszi ilyenfajta csoportosításukat.

3. A városhierarchia különbözổ szintjein, a települések központi funkciói milyen mozgásteret biztosítanak a kisipar, a kiskereskedelem és a szolgáltatások számára? A gyáripar, a nagykereskedelem milyen munkamegosztást alakít ki a kisiparral, a kiskereskedelemmel és a szolgáltatások kisvállalkozóival? Milyen eltérések vannak ebben a vonatkozásban a városhierarchia különböző szintjein? A kispolgári rétegeknél a gazdasági tôke megôrzése milyen színvonalú és szerkezetû kulturális tônkét igényel? A kispolgári rétegek attitüdjei mennyiben épülnek a felülrôl ,,leszivárg6" mintákra, és mennyiben saját "értékteremtésük" eredményei. 
4. A munkásság - ezen belül a nagyipari munkások - aránya és belsố tagoltsága hogyan változik a városhierarchia különbözố szintjein? A munkásság gazdasági érdekvédelmi, politikai és kulturális szervezeteit mennyire tudja befolyásolni az állam és a tốkésosztály?

5. S végül, de nem utolsó sorban: az egyes társadalmi rétegek és csoportok között orszá- gos szinten milyen mértékủ a társadalmi mo. bilitás, $s$ milyen település-specifikus vonása vannak ennek a folyamatnak? A társadalm. helyzet változtatásában milyen szerepe van : gazdasági tốke felhalmozásának, illetve a kul. turális és szimbolikus tôkének? A társadalm mobilitási folyamatok milyen mértékben kap. csolódnak össze a földrajzi mobilitással?

Timár Lajos

\section{Európa éghajlata a középkor idején \\ Alexandre, P. (1987): Le climat en Europe au Moyen Age (1000-1425), Paris, EHESS, 822 p.}

A történettudomány és a klimatológia egymástól igen távol esổ diszciplínák, amelyeket egyszerre aligha lehet színvonalasan múvelni. Alátámasztja ezt az állítást az is, hogy a két tudomanány diszciplináris határa egybeesik a természet- és a társadalomtudományok választóvonalával. Mûvelésükhöz, ennek megfelelốen, alapvetổen különbözớ gondolkodásmód, ismeretek és módszerek szükségeltetnek.

P. Alexandre belga (klíma)történész ennek a szakmai berkekben is széles körben elfogadott felfogásnak adta látványos cáfolatát a történeti középkor éghajlatáról szóló munkájában. Abban, hogy a filológus alapképzettségú történész eljusson a klímaingadozások problémájához, komoly része volt egyrészt a szerzô édesapjának, aki a liège-i egyetem Természeti Földrajzi Tanszékének professzora. Másrészt az Annales-Kör olyan történészeinek, mint F. Braudel és E. Le Roy Ladurie. P. Alexandre 1973-ban választotta doktori értekezésének témájául a középkori Európa éghajlattörténetének vizsgálatát. A belga történész elemzései jól illeszkedtek az európai , Éghajlattörténeti rekonstrukció" klimatoló- giai programjába, ezért $P$. Alexandre kutatási költségeit az Európai Gazdasági Közösség fedezte. Az elkészült doktori értekezésı 1983-ban védte meg a belga kutató, ennek a munkának átdolgozott változatát jelentette meg könyv alakjában az École des Hautes Études en Sciences Sociales (EHESS).

A történeti korok éghajlatának elemzése, amit a belga történész az 1970-es évek elején kezdett vizsgálni, nem volt teljesen új kutatási irány. Ekkor már megjelent több, a témában ma is alapvetổnek számító mú, így C.E.P. Brooks és H.H. Lamb elemzései a középkori és újkori Európa klímatörténetérổ. Közös gyengéje volt viszont ezeknek a munkáknak, hogy adatbázisuk kialakítása során jelentôs mértékben támaszkodtak a középkori kútfốk olyan megbízhatatlan gyứjteményeire, mint amilyenek C. Easton, E. Vanderlinden és F. Arago forráskiadásai voltak. P. Alexandre, felhasználva filológiai iskolázottságát, a különféle kompilációkban már feldolgozott, illetve a saját levéltári kutatásai során feltárt éghajlattörténeti vonatkozásokat tartalmazó forrásokat rendszeres történeti kritikának vetette alá. 